\title{
Needs Analysis: Development of Local Excellence- Based Reading Texts to Improve Communication Skills of Tour Guides in Papua
}

\author{
Nicodemus Bisse ${ }^{1 *}$, Lalu Suhirman ${ }^{2}$ \\ Universitas Cenderawasih, Indonesi ${ }^{1}$ \\ Universitas Cenderawasih, Indonesia ${ }^{2}$ \\ \{nikobais@yahoo.co.id ${ }^{1}$, lalusuhermanmpd@gmail.com² ${ }^{2}$,
}

\begin{abstract}
This paper describes the initial stages of a needs analysis project developed in the context of tourism in Papua with the aim of identifying the needs of the target group of learners (tour guides) and introducing local excellence-based reading text courses and teaching materials. This study adopted the needs analysis framework suggested by Hutchinson and Waters (1994) focusing on target needs and learning needs. The research findings reveal the need for the development of very specific English courses or what is often called as 'English for Specific Purposes' (ESP) with a clear focus on the target discipline, tourism in Papua. There is also a demand for ESP training provision which addresses the urgent needs of tour guides and their king-term needs as professionals in the tourism business.
\end{abstract}

Keywords: need analysis; tourism; tour guide local excellence bused reading text; ESP

\section{Introduction}

In line with the objectives of the strategic plan of the University of Cenderawasih and the vision and mission of the Chancellor of Cenderawasih University for 2017-2021, namely to make Uncen a high quality and relevant higher education in the Eastern Indonesia region to the needs of national development so that it contributes significantly to increasing the competitiveness of the nation, research institutions and community service (LPPM) namely that this can be achieved through research and community service in higher education. If we reflect on developed countries, it cannot be denied that one of the main factors supporting progress is the quality of education, research, community service which is constantly moving forward, so it is only natural that the quality of their research is at the forefront of the science arena.

Tourists who visit tourist destinations in Papua who come from abroad have different cultural and linguistic backgrounds and need precise, correct and accurate information. For certain purposes, tourist' need information based on specific reasons or purposes. for example, tourism with historical, religious, professional, and research purposes in addition to their general purpose, traveling to enjoy the beauty and uniqueness of nature and culture, artistic attractions and wisdom. local which refreshes the body and soul from tourist fatigue due to 
work that is done routinely every day. English is the language of international communication which can be the main media used by tourism industry players to provide and convey the information needed by tourists. By having English communication skills, tourism industry players can convey clear and accurate information based on the travel needs of tourists.

The phenomenon seen in each tourism industry is that the interaction between tourists and managers is still low, this is because the ability to communicate using English is still limited, so that it has an impact on decreasing the length of staying program for tourists. 'Therefore. this research program will develop a teaching material to improve English communication skills based on local excellence for tourism industry players to increase the volume of tourist visits both in terms of the length of stay of tourists and the number and volume of tourist visits to Papua.

\subsection{Problem Formulation} problems

Based on the above background, the researcher formulates the following research

1. What is the need for teaching materials to improve English communication skills for tourism industry pliers in Papua?

2. What is the learning model needed by tourism industry players in Papua to improve English communication skills?

3. How are the teaching materials developed with due observance to existing local wisdom to improve English communication skills for tourism industry players in Papua?

\subsection{Research Objectives}

Based on the problem formulation above, the excellent research program produces outputs in the form of international publications, IPR (patent, simple). method design. prototypes, strategic blue models and national scale. This research is also expected to produce additional outputs such as accredited national journals, regional. and local, proceedings and textbooks. Instead of those objectives, in particular, the basic objectives of this part of the research project were :

- to identify the students' prospective professional needs;

- to identify the students' needs In terms of language skills and task.

- to record the students' deficiencies concerning language skills;

- to elicit the students' preferences with respect to learning styles, methodology, and teacher roles;

- to record the students' suggestions for better ESP training.

\section{Literary Review}

Based on research studies produced by researchers to obtain doctoral academic qualifications, namely a study on the development of Speaking Teaching Materials for Independent Study with the research title is "Developing Speaking Instructional Materials to Promote Autonomous Learning for Senior High School Students in Makassar (Nicodemus, 2016), and international journals. with a reputation, with the title "Developing Speaking Instructional Material Base On Autonomous Learning for Senior High School Students in Makassar (Nicodemus, 2016). Several articles through national journals that examine the design and development of English teaching materials for specific purposes art published 
through reference books, dissertation research and international and national journals, including the

Application of Pair Works Technique in

Teaching Speaking to The Second Semester Students of English Department of STKIPYPUP Makassar and Utility of Self-Access Materials in Language Learning for Autonomous learners. Both journals, indexed by Scopus.).

In connection with the proposal submitted for the flagship schematic grunt program, which focuses on the design and development of English language teaching materials for specific purposes (ESP) to improve English communication skills for players in the Papua tourism industry. To achieve lecturer expertise in the research field, the following is the head of the researcher making a research map (road map) as a reference and reference support for this research.

\subsection{Research methods and tools}

A multi-method approach involving both quantitative and qualitative research methods was adopted in the needs analysis project. Triangulation of sources and methods (JassoAguilar. 1999; Long. 2005) was also attempted to secure the validity and reliability of the study. Data collection was carried out through a student questionnaire, which included closed and open questions and was given to 20 participants Moreover, semi-structured interviews were conducted with 5 tourism service employees in an effort to gain more meaningful insights into the situation.

\subsection{Data Analysis Techniques}

Questionnaires (closed questionnaires) and checklists using a Liken scale with an average value between 1-5. For example, measuring "importance" can be explained as follows: the value of 1 is not very important, $2=$ not important, $3=$ moderate, $4=$ important and 5 = very important, by applying the generally accepted rounding up and vice versa. For the purpose of the priority scale of the perception of learning needs, the researcher will analyze by calculating the average value to get the priority scale. The task of each member of the research team is together with the head of the researcher to compile research instrument, retrieve data, manage data and compile reports on results and outputs or products, both mandatory products and additional outputs in accordance with the promises in this research. The data obtained from the questionnaire were analyzed using descriptive statistical methods. Frequencies and percentages for all questionnaire items were obtained. The semi-structured interview verbal data were analyzed qualitatively by data reduction procedures, first and second level coding and pattern coding. The code generates a category group, 'labeled' with a specific name (Miles \& Huberman, 1994). Then, similar concepts with the same characteristics arc grouped into themes.

\section{Finding}

As been presented on findings, the result of the research using data analysis Technique : Questionaires (closed questionaires) and check list using a linkers leak with an average value between 1-5 for example, measuring "importance" can be explained as follows the value of I is no wry important and $2=$ not important, $3=$ moderate, $4=$ important and $5=$ very importance, by applying the generally accepted rounding up and vice versa. The data obtained from the questionnaire were analysed using descriptive statistical methods. Frequencies and 
percentages for all questionnaire items ware obtained the semi-structured interview verbal data were analy $7 \mathrm{~cd}$ qualitatively by data reduction procedures. fast and second level coding and pattern coding the code generate a category group.

\section{Conclusion}

Based on the findings and discussion the research concluded that the needs of the target group of learners (tour guide) and introducing local excellence based reading text courses and teaching materials there is also demand for ESP training provision which address the urgent needs of tour guide and thins long term needs as professional in the tourism business.

\section{References}

[1] Bisse Nicodemus (2016) Developing Speaking Instructional Material to Promote Automnomus Learning For Senior High Schooling Makassar

[2] Branch. Robert Maribe.2010. Instructional Design : The ADDIE Approach. London; Springer.

[3] Bygate, M. (1987). Speaking Oxford: Oxford University Press.

[4] Ellis, M. and EllisP (1987) Learning By Design: Some Design Criteria for EFL Coursebook. In L.E. Sheldon (ed) ELT Textbook and Materials. Oxford Modern English Publication in Associates with The British Council.

[5] Hutchinson. T and Waters, A 1987. English for Specfk Purposes 'A learning centredapproach. P (1987)h' New York: Cambridge University Press

[6] Miley, J.Y. 2008. The MMS Instructional Design. United States: Capella University

[7] Ratnah. (2013). Developing English For ESP Course For Tours and Travel Students Based on Need Analysis

[8] Sudirman (2017) Pelatihan Metodologi Riset Terbaru tahun pada tanggal 4-5 Pebruari 2017

[9] Satori, Djam'an. 2010. Peningkatan dan Penjaminan Mutu Pendidikan, Bandung: up'

[10] Sudirman (2017) Filosofl dan Jenis Penelitian Materi Pelatihan Metodologi Riset terbaru 2017. Palopo. 4-5 Februari 2017.

[11] Bisse, Nichodemus (2016) Utility of self - acces materials : for autonomous Leaner thr Asian EFL.Journal.

[12] Bisse, Nichodemus 2017. Developing Speaking Instructional Material Best On Autonomous Learning For Senior Nigh School in Makassar.

[13] Samad, Noersal (2015) Indonesian Tour Leader Asostiation. Retrired 20 March 2016 from http://,facebook. Com/ITLA fans/posts/. 